\title{
IMPACT OF THE SYSTEM OF AIR SUPPLY TO A MILKING UNIT ON SELECTED PARAMETERS OF MILKING MACHINE OPERATION
}

\author{
Marian Wiercioch*, Adam Luberański, Aleksander Krzyś, Danuta Skalska, Józef Szlachta \\ Institute of Agricultural Engineering, Wroclaw University of Environmental and Life Sciences \\ *Corresponding author: e-mail: marian.wiercioch@up.wroc.pl
}

\begin{tabular}{|c|c|}
\hline ARTICLE INFO & ABSTRACT \\
\hline $\begin{array}{l}\text { Article history: } \\
\text { Received: January } 2016 \\
\text { Received in the revised form: } \\
\text { February } 2016 \\
\text { Accepted: March } 2016\end{array}$ & $\begin{array}{l}\text { Air is supplied to a milking machine installation most usually in } \\
\text { a constant manner by supply of a small amount of air to a milking } \\
\text { chamber of a claw or periodically to a connection pipe of a liner, } \\
\text { which enables milk outflow to a milking pipe and improves stabiliza- } \\
\text { tion of vacuum and limits its fluctuations. On the market of milking }\end{array}$ \\
\hline $\begin{array}{l}\text { Key words: } \\
\text { machine milking, } \\
\text { milking machine, } \\
\text { milking parameters, } \\
\text { vented gums }\end{array}$ & $\begin{array}{l}\text { machines there is a new solution in the form of mouthpiece vented } \\
\text { liners - impulseair }{ }^{\mathbb{B}} \text {, where air is supplied constantly by a calibrated } \\
\text { nozzle in the head of a liner. The objective of the paper was to analyse } \\
\text { and assess the selected parameters of milking determined in a milking } \\
\text { machine with a claw with fixed volume of a milking chamber ( } 250 \\
\mathrm{~cm}^{3} \text { ) with mouthpiece vented liners in comparison to other solutions } \\
\text { used for air supply in milking machines. Measurements were carried } \\
\text { out in laboratory conditions with milking to the upper milk pipeline, at } \\
\left.\text { variable mass intensities of liquid flow (within } 0-8 \mathrm{~kg} \cdot \mathrm{min}^{-1}\right) \text {, for three } \\
\text { penetrations of artificial teats ( } 46,48,62 \mathrm{~mm}) \text {, at three values of the } \\
\text { system vacuum ( } 46,48 \text { and } 50 \mathrm{kPa}) \text {. A significant impact of the } \\
\text { manner of air supply to a milking machine and remaining independent } \\
\text { variables of an experiment on the selected milking parameters was } \\
\text { proved with the use of a statistical analysis. It was found that a milk- } \\
\text { ing unit with mouthpiece vented liners, although it reduces average } \\
\text { vacuum of suction [pss], at the same time it limits fluctuations of } \\
\text { underpressure in the dp cycle. }\end{array}$ \\
\hline
\end{tabular}

\section{Introduction}

A correctly functioning milking unit aims at fast, safe and precise emptying of a cow's udder and according to requirements of milk processing plants it is additionally emphasised that it must be high quality milk (Rasmussen and Madsen, 2000). The requirement of fast milking is mainly the reason for their higher milking efficiency and limited time of occurrence of oxytocin hormone in blood which is indispensable for correct milking. In literature it is assumed that safe milking means suitable pressure conditions (without decrease and fluctuations) within a cluster particularly in a milking cup and correct cooperation of a liner with a teat of a milked cow (Harms, 2009). In order to limit decrease and fluctuations of vacuum in a traditional cluster it is recommended to introduce atmospheric air to the milking system of a milking machine (Kupczyk, 1999; Szlachta, 1986). The main function of air 
supply to a cluster is speeding up milk outflow from a claw to a milking pipe and reduction of density of the stream of milk and air mixture which flow to the upper milk pipeline (reduction of pressure drops on the raise of milk and air streams). Literature provides a big discrepancy of the research results and opinions on the desired volume of air stream supplied to a cluster. According to Nordegren (1980) the recommended air volume stream is approx. $9 \mathrm{dm}^{3} \cdot \mathrm{min}^{-1}$ of free air and the ISO recommendations based on Kerhoff's research (1972) indicate the range of 4-12 $\mathrm{dm}^{3} \cdot \mathrm{min}^{-1}$. Rossing (1970) compared streams of volume of the supplied air including claws' volume and stated that in case of a very small claw $\left(27 \mathrm{~cm}^{3}\right)$, the minimum should be $7 \mathrm{dm}^{3} \cdot \mathrm{min}^{-1}$ and in case of a big claw $160 \mathrm{~cm}^{3}$ a recommended stream of volume of the supplied air is $5-6 \mathrm{dm}^{3} \cdot \mathrm{min}^{-1}$.

The results of the research on the manner (periodically or constantly) and the place of introduction of air to a cluster (to a claw, to a connection pipe and a solution suggested by Milkrite company under the name "vented gums impulseair ${ }^{\circledR}$ ", where air is supplied through a calibrated nozzle in the head of a teat gum) on the vacuum stability (Rasmussen, et al., 2006). The results indicate that during a simulated milking with a traditional milking machine better results were achieved at the constant air supply with an opening placed in the upper cover of a claw (Nordegren, 1980; Szlachta, 1986). High cyclic fluctuations of vacuum were observed in traditional clusters in case there were no openings which supply air to a claw as well as with small volume claws (Szlachta, 1986; Wiercioch, 1994; Wiercioch et al., 2013). Moreover, at the absence of air supply a long milk pipeline will be completely filled with milk and the vacuum drop will mainly depend on the hydrostatic pressure. For example, if milk stream is transported at $1 \mathrm{~m}$ height, drop of vacuum will be $10.5 \mathrm{kPa}$ (Szlachta and Wiercioch, 1988). Along with the raise of the air volume stream supplied to a cluster a drop of hydrostatic pressure takes place and on the other hand, the speed of milk and air mixture flow increases and thus flow resistance raises (Kupczyk, 1999). Advantages of clusters with a periodical air supply in comparison to traditional clusters indicated by Hofelmayer and Meier (1979), Szlachta and Wiercioch (1984) and Szlachta (1986) consisting in a considerable improvement of vacuum stabilization and maintaining at a higher level in the sucking phase concerned mainly their comparison to traditional clusters with collectors with a cluster volume of approx. $150 \mathrm{~cm}^{3}$ and lower intensity of milk flow.

It was noted (Lipiński and Czarnociński, 1995; Wiercioch et al., 2013) that along with the increase of the milk mass stream and along with the increase of the height of milk there are considerable drops and fluctuations of vacuum in a cluster.

In majority of studies a thesis prevails according to which reduction of vacuum fluctuation in a milking part of a cluster is necessary. ISO 5707 standard of 1983 admitted occurrence of vacuum fluctuations in a cluster which do not exceed $15 \mathrm{kPa}$. Presently applicable standard ISO 5707 of 2007 recommends the lowest possible fluctuations of vacuum in a milking part of a cluster without providing their value.

In the available branch literature there is no full information concerning the impact of a cluster equipped with mouthpiece vented liners (impulseair ${ }^{\circledR}$ ) on milking parameters, although (observations and results of producer's investigations) their advantageous impact on a teat (Vetter, et al., 2014) is emphasised. According to a producer, nozzles located in a flange of teat gums ensure equal air flow at the same time reducing the pressure on a teat. As a result outflow of milk is more effective, teats remain dry and the risk of teat damage is reduced, e.g. hyperkeratosis (www.1). These opinions are not confirmed by observations 
Impact of the system...

and initial research of two leading producers of clusters DeLaval and GEA (www.2; www.3).

\section{Objective of paper}

The objective of the paper was analysis of the selected parameters of milking in a cluster equipped with vented liners impulseair ${ }^{\circledR}$ and their comparison with the results obtained in clusters with other methods of air supply to the milking installation i.e. constantly to a claw or periodically to the connection pipe of a liner. On account of the significant impact of the volume of a milking chamber on the milking parameters one type of a claw was used in the investigated variants.

\section{Object, scope and method of research}

For ensuring realization of the objective of the paper in all variants of clusters Orbiter 250 claw with the milking chamber volume of $250 \mathrm{~cm}^{3}$ and straight connection pipes, with a diameter of $\phi=13 \mathrm{~mm}$ with which one of three sets of milking cups were connected in relation to the selected measurement option, were used (fig.1). In the research standard milking cups Milkrite with vented liners with a triangular cross section of the body part (impulseair ${ }^{B}$ ) type IP10U and non-vented of the same type and biomilker cups with round liners Westfalia Separator 7022-2725-150 were used. In case of the first measuring option in front of each liner impulseair ${ }^{\circledR} 8.31 \cdot \mathrm{min}^{-1}$ of free air was supplied and the vent which supplies air to a claw was blocked. In the second option with non-vented gums IP10U air was supplied to a claw in the amount of $51 \cdot \mathrm{min}^{-1}$. In the third option similarly to the first one, air supply to a claw was blocked and through a biomilker valve $31 \cdot \mathrm{min}^{-1}$ of free air flowed periodically to the liner connection pipe.

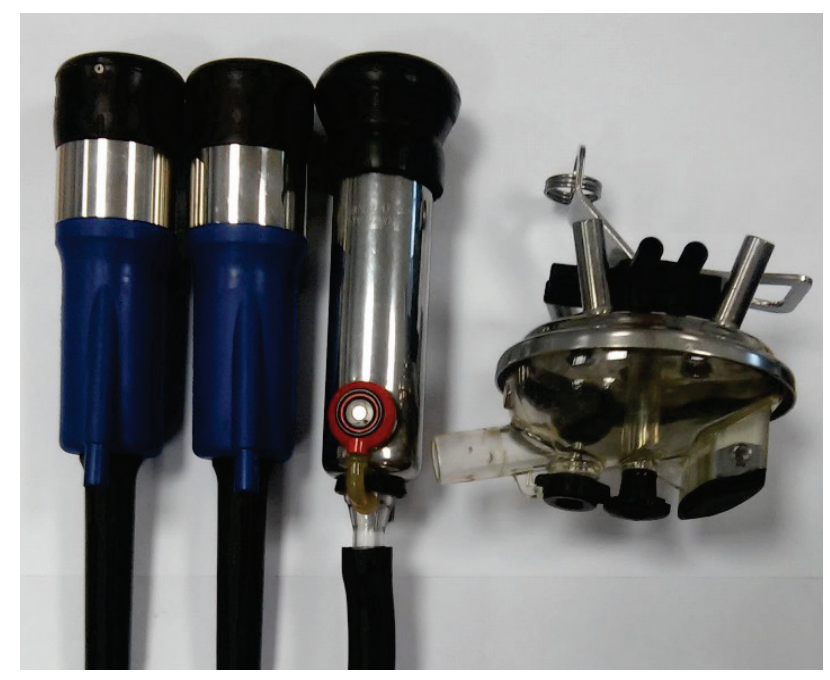

Figure 1. Milking cups and cluster of the investigated options of clusters 
The research was carried out in a milking laboratory of the Institute of Agricultural Engineering in Wroclaw under conditions of simulated milking on the measurement stand built based on the installation of a pipeline cluster with a milk pipeline located at the height of $1.9 \mathrm{~m}$ (fig. 2). Milk replacing liquid was provided to milking cups with artificial teats with the structure pursuant to ISO 6690 standard (2007) with the length of 100, 75, 62 and $50 \mathrm{~mm}$. Intensity of mass stream of liquid flowing through a cluster was changed within 0 to $8 \mathrm{~kg} \cdot \mathrm{min}^{-1}$ every $2 \mathrm{~kg} \cdot \mathrm{min}^{-1}$, with the use of a rotameter (Kÿtöla). The unit operation was controlled by a pulsator with pneumatic dampening (with pulsation frequency $1 \mathrm{~Hz}$ and coefficient of a pulsator $(60 \%)$ with alternating pulsation.

Working underpressure in a vacuum installation was generated by a pump with efficiency of $51 \mathrm{~m}^{3} \cdot \mathrm{h}^{-1}$ (Westfalia) and maintained at a relevant level by Vacurex 5000 valve. Working underpressure applied in the research was 50,48 and $46 \mathrm{kPa}$. The investigated variants of clusters were connected with a long milk conduit with a diameter of $18 \mathrm{~mm}$ to a milk pipeline (located at $1.9 \mathrm{~m}$ height) with a tap and Combi Standard connector.

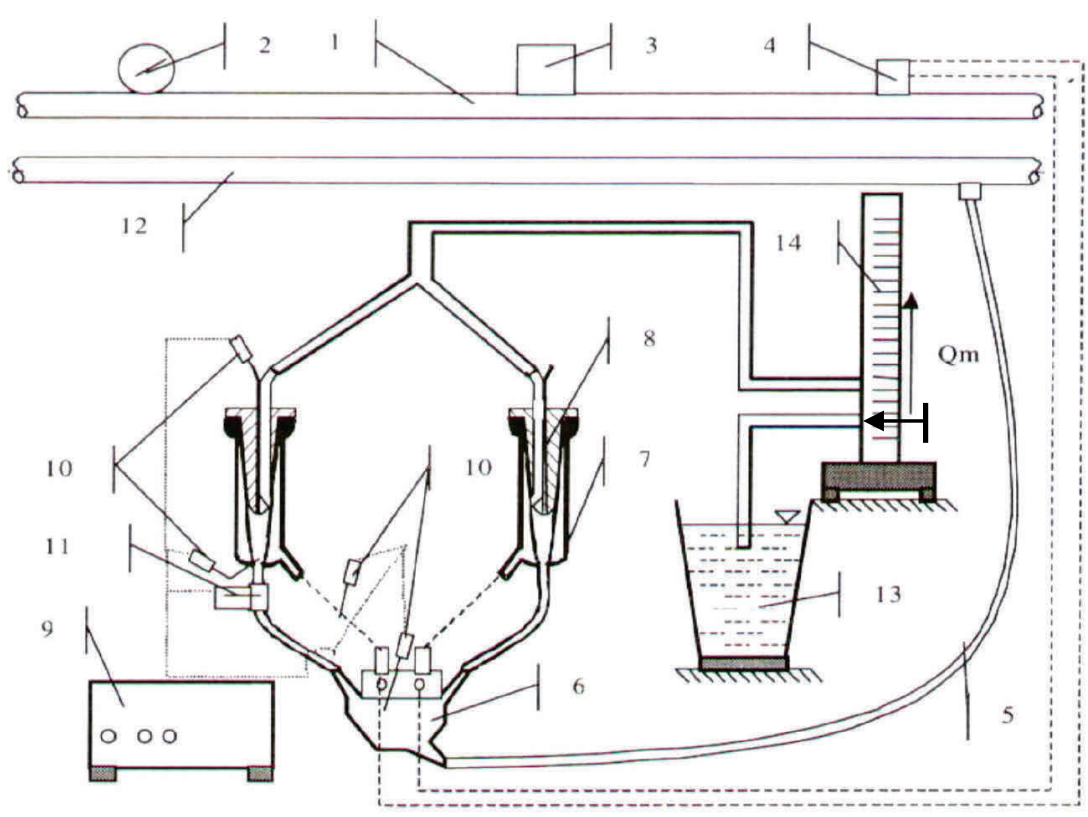

Figure 2. Schematic representation of measurement stand: 1 -vacuum pipeline, 2 - vacuum gauge, 3 -vacuum regulator, 4 - pulsator, 5-long milk pipeline, 6-claw, 7 - teatcup, 8 - artificial teat, 9 - recorder, 10 -vacuum sensors, 12 - milking pipeline, 13 - tank with milk replacing liquid, 14 - rotameter with flow regulator

Measurements of vacuum changes at the end of a teat in a teat chamber, in a milk chamber of a cluster and short pulsation conduit were carried out with current vacuum transducers SML (ADC-Eltek) of 0.25\% class (measurement scope 0-60 kPa). Signals from 
Impact of the system...

transducers were recorded by a recorder comprising a four-module base NIcDAQ 9174 equipped with two current modules NIcDAQ 9203 and one voltage NIcDAQ 9237. Recording of signals measured with sensors took place with $400 \mathrm{~Hz}$ frequency directly at the computer disc according to a configuration defined in the application "Symulacja", which is designed for determination of milking parameters (Luberański et al., 2013). From the determined parameters the following were selected for a detailed analysis: average vacuum of suction [pss], average drop of vacuum in the dpsr cycle and fluctuations of vacuum in $\mathrm{dp}$ cycle. Then, the registered data were processed in Excel program.

\section{Research results}

A multi - variate analysis of variance (tab. 1) carried out with the use of Statgraphics 6.0 statistic application proved a significant impact on the selected milking parameters of all independent variables of an experiment except for under pressure fluctuations in the $\mathrm{dp}$ cycle in case of applied systemic vacuum. The fact that the obtained results indicate explicitly statistically significant change of the analysed milking parameters at varied manner of air supply to a cluster (variants of clusters) as well as prevailing impact on shaping intensity of the mass stream of the flowing liquid should be emphasised.

Table 1.

Results of multi-factor analysis of variance of impact of independent variables of experiment on analysed milking parameters: average vacuum of suction [pss], average decrease of vacuum in the dpsr cycle and fluctuations of vacuum in the dp cycle

\begin{tabular}{|c|c|c|c|c|c|}
\hline $\begin{array}{l}\text { Milking } \\
\text { parameter }\end{array}$ & $\begin{array}{l}\text { Source } \\
\text { of } \\
\text { variability }\end{array}$ & $\begin{array}{c}\text { Variant } \\
\text { of a cluster } \\
T \\
T\end{array}$ & $\begin{array}{c}\text { Systemic } \\
\text { underpressure } \\
P\end{array}$ & $\begin{array}{c}\text { Mass } \\
\text { intensity } \\
\text { of liquid flow } \\
Q m\end{array}$ & $\begin{array}{c}\text { Teat } \\
\text { penetration } \\
P e\end{array}$ \\
\hline \multirow{3}{*}{$\begin{array}{l}\text { Average vacuum } \\
\text { of suction pss }\end{array}$} & $\begin{array}{l}\text { Number } \\
\text { of degrees } \\
\text { of freedom }\end{array}$ & 2 & 2 & 4 & 3 \\
\hline & $\begin{array}{c}\text { Level } \\
\text { of significance } \alpha\end{array}$ & 0.000 & 0.000 & 0.0000 & 0.010 \\
\hline & $\mathrm{F}$ test values & 79.854 & 427.831 & 4100.293 & 3.828 \\
\hline \multirow{2}{*}{$\begin{array}{l}\text { Average drop } \\
\text { of vacuum in } d p s r \\
\text { cycle }\end{array}$} & $\begin{array}{c}\text { Level } \\
\text { of significance } \alpha\end{array}$ & 0.000 & 0.000 & 0.0000 & 0.010 \\
\hline & $\mathrm{F}$ test values & 94.058 & 9.660 & 5528.272 & 3.826 \\
\hline \multirow{2}{*}{$\begin{array}{l}\text { Fluctuations } \\
\text { of vacuum } \\
\text { in } d p \text { cycle }\end{array}$} & $\begin{array}{c}\text { Level } \\
\text { of significance } \alpha\end{array}$ & 0.000 & 0.995 & 0.0000 & 0.000 \\
\hline & F test value & 21.221 & 0.005 & 834.468 & 16.528 \\
\hline
\end{tabular}

Figure 3 presents the indicated relations of average vacuum of suction $p s s$ as a function of mass stream of the liquid flowing through the cluster $Q_{m}$ for various methods of air supply to a $62 \mathrm{~mm}$ cluster. On account of high probability of courses for the remaining penetra- 
tions their detailed analysis was withdrawn, although a trend can be noticed that longer teats have lower pss values. Average vacuum of suction pss defines conditions of milking in the aspect of keeping teats in a protruding position maintaining thus patency of a teat channel and a correct outflow of milk in the suction phase.

The relations presented in figure 3 prove that the change of the working vacuum, increase of the intensity of the stream of mass of the flowing liquid and mainly a cluster variant, which includes methods of air supply has a significant impact on pss values. At low flows of liquid, differences in the pps parameter value in the investigated variants of clusters are very low and are visible only at high flows of liquid.
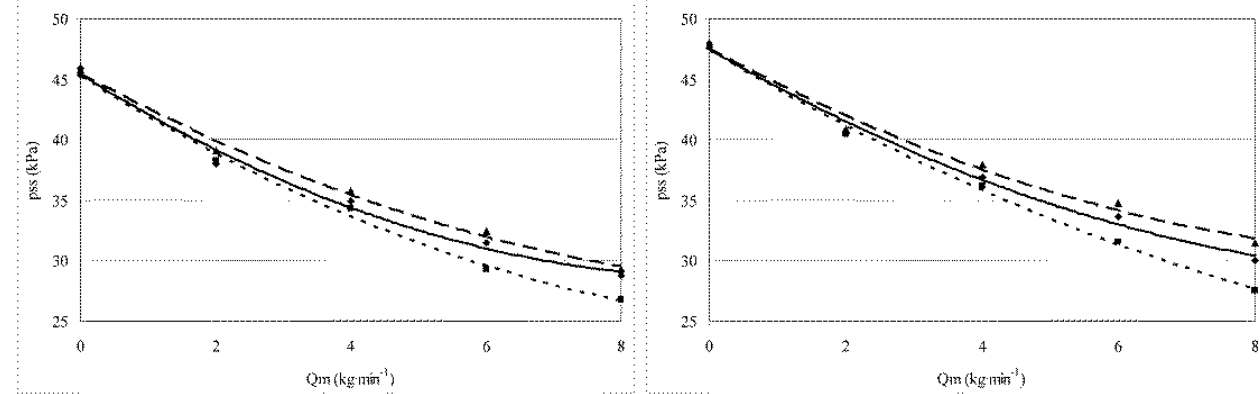

C)

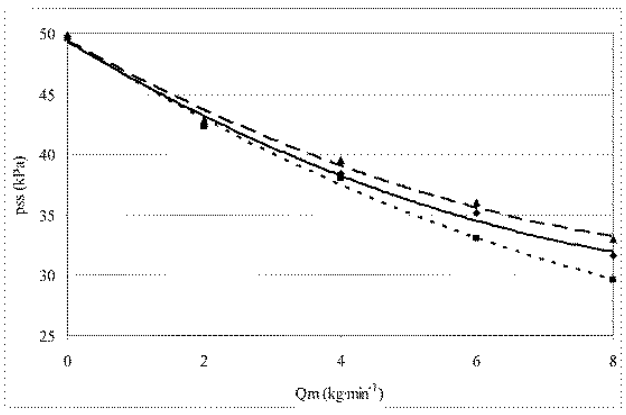

- $\mathrm{B}=\mathrm{MD} \wedge \mathrm{MK}$

Symbols:

B - biomilker cluster

MD - cluster with vented liners

MK- cluster with air supply to a claw

Figure 3. Impact of mass intensity of liquid flow Qm on average vacuum of suction pss in the investigated variants of clusters for penetration of a teat $P e=62 \mathrm{~mm}$ at the systemic vacuum: $A-46 \mathrm{kPa}, \mathrm{B}-48 \mathrm{kPa}, \mathrm{C}-50 \mathrm{kPa}$

Due to high supply of free air through a nozzle in the head of each of four liners $(8.3$ $1 \cdot \mathrm{min}^{-1}$ ) the lowest courses of pss relation in the Qm function (the highest reduction of the value of average vacuum of suction) for each of the used systemic vacuums were observed for a cluster with vented liners and the highest for the variant of a cluster with triangle liners (non-vented) and air supply to a cluster. Biomilker milking machine is in the centre of these relations at low intensity of liquid flow Qm and at high flows its course gets closer to a curve of a cluster with air supply to a claw. At the systemic vacuum of $48 \mathrm{kPa}$ which is recommended for clusters with an upper pipeline for a considerable flow of liquid $\mathrm{Qm}=8 \mathrm{~kg} \cdot \mathrm{min}^{-1}$ average vacuum of suction pss drops to the value of $27.3 \mathrm{kPa}$ for 
Impact of the system...

the option of a cluster with vented liners, to $30 \mathrm{kPa}$ for biomilker cluster and to $31.5 \mathrm{kPa}$ for a cluster with air supply to a claw, while at the average flow of $4 \mathrm{~kg} \cdot \mathrm{min}^{-1}$ these values were respectively $-36.2,36.9$ and $37.9 \mathrm{kPa}$. The lowest pss values measured in case of a cluster with triangle vented liners may result in a lower mechanical load of a teat and in particular of its channel in the suction phase. Therefore, more advantageous effects of damage, swelling and livid teats of milked cows in comparison to round liners were reported by the producer of these liners (www.1). The results of the pss analysis indicate, in particular for a cluster with vented liners, for assumed measurement conditions that a correct mechanical milking can be carried out at a border milk flows which are up to $8 \mathrm{~kg} \cdot \mathrm{min}^{-1}$ in particular of a correct outflow of milk in the suction phase. At the same time, tests on milk would be recommended because of a great amount of supplied air to this cluster on account of fats oxidation in milk.

An important parameter which proves the stability of pressure conditions in a cluster is an average drop of pressure in the dpsr cycle (fig.4). The value of this parameter and its changes cause that milk may be accepted from a teat chamber to a claw and a cluster is fixed to teats (too high value of dpsr above $20 \mathrm{kPa}$ threatens safe milking and causes that a cluster may slide from teats). Analysis concerning the course of curves of average vacuum decrease in the cycle (Fig. 4) for the investigated variants of milking machines was carried out based on the intensity of the flowing liquid mass stream. With low and average (at the level of up to $4 \mathrm{~kg} \cdot \mathrm{min}^{-1}$ ) flows of milk replacing liquid for vacuum applied in research, dpsr values do not exceed $13 \mathrm{kPa}$. Maximum values of this parameter were determined for working vacuum of $50 \mathrm{kPa}$ at $\mathrm{Qm}=8 \mathrm{~kg} \cdot \mathrm{min}^{-1}$ and are within up to $19.1 \mathrm{kPa}$ for the variant of a cluster with liners with a triangle cross section of tubes and air supply to a claw to $21.5 \mathrm{kPa}$ for a cluster with vented liners. For Biomilker cluster for the same conditions research dpsr is $19.8 \mathrm{kPa}$. At the remaining systemic vacuum, values of this parameter are at a slightly lower level.

The obtained values of the considered parameter during a simulated milking indicate that the milking process may be disturbed at high flows of milk in case of a unit with vented liners because teat cups are not strongly fixed to teats, which may be partially reduced by a triangle structure of the body part of a liner. In this context one should pay attention to the fact that dpsr parameter includes also decrease of vacuum in the massage phase. Thus one may expect a poor teat massage, not complete closing of a liner under a teat in the massage phase of a teat which is an unfavourable phenomenon for the milking process course and the condition of a healthy teat similar reservations were presented based on the initial observation and research with the use of triangle liners by cluster producers DeLaval and GEA (www.2; www.3). On the other hand, there are no such unfavourable remarks in the paper by Vetter et al., (2014), where research results of a similar system AktivPuls® by Happel were presented.

Fluctuations of vacuum within a cluster are a hazardous factor which influences more often mastitis diseases. They may also insufficiently or unevenly stimulate a cow for milking, elongate milking time. Vacuum fluctuations are affected by numerous factors, among which intensity of the stream of the flowing liquid mass and structural solutions of a cup and a cluster is fundamental. Registered dp values as a function of Qm (fig. 5) for the investigated variants of clusters are typical courses in case of milking with alternating pulsation and they differ with a variant of the used cluster. Decisively the highest fluctuations of vacuum within the flows up to $6 \mathrm{~kg} \cdot \mathrm{min}^{-1}$ are generated by a cluster with a periodical air 
supply to a connection pipe of a biomilker type liner. Dp values measured for this scope of value flows are by approx. $2 \mathrm{kPa}$ higher than the remaining variants. At maximum flows $\left(8 \mathrm{~kg} \cdot \mathrm{min}^{-1}\right)$ differences between the dp values for particular variants are not as considerable. The lowest dp values in the entire scope of applied liquid flows were reported for the cluster with vented teat liners with triangle cross section of tubes. With regard to this solution, a variant of a cluster with triangle teat liners (without ventilation) and air supply to a cluster generates by 5 to $10 \%$ higher fluctuations of vacuum. From the comparison of the investigated clusters within $\mathrm{dp}$, it may be recognized that the structure of a cluster with vented liners affects more stability of mechanical milking than other solutions.

A)

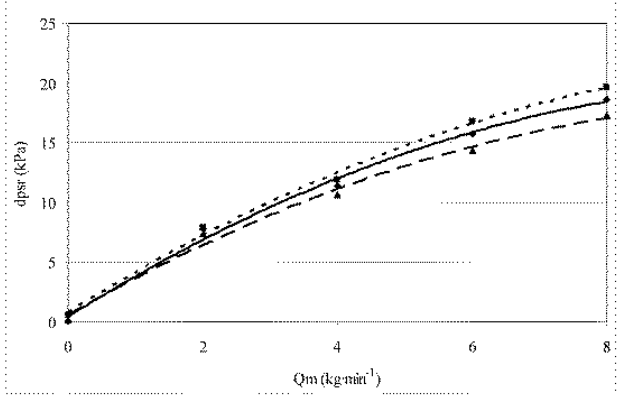

C)

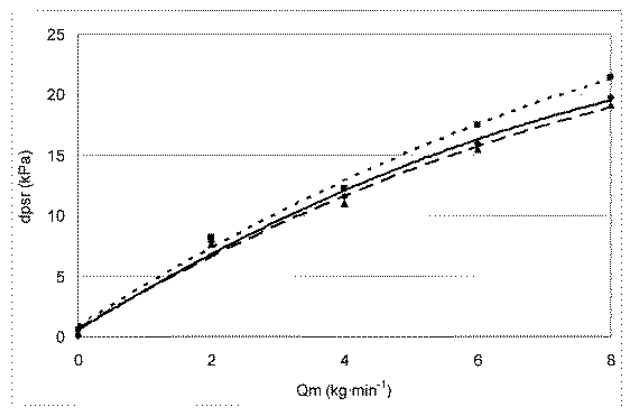

B)

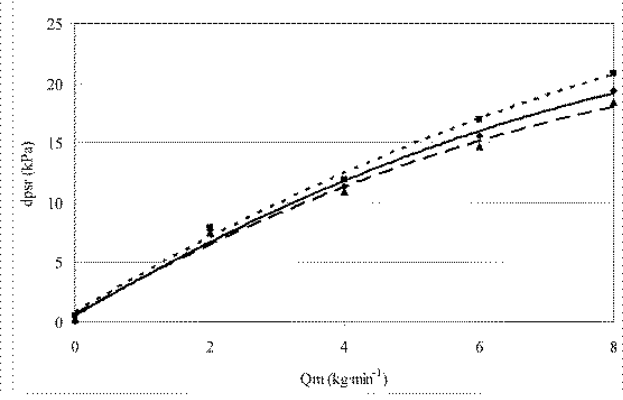

- $\mathrm{B} \approx \mathrm{MD} \wedge \mathrm{MK}$

Symbols

$\mathrm{B}$ - biomilker cluster

$\mathrm{MD}$ - cluster with vented teat gums

MK- cluster with air supply to a claw

Figure 4. Impact of mass intensity of liquid flow $Q m$ on average reduction of vacuum in dpsr cycle in investigated variants of clusters for penetration of a teat Pe $=62 \mathrm{~mm}$ at systemic vacuum: $A-46 \mathrm{kPa}, B-48 \mathrm{kPa}, \mathrm{C}-50 \mathrm{kPa}$ 
A)

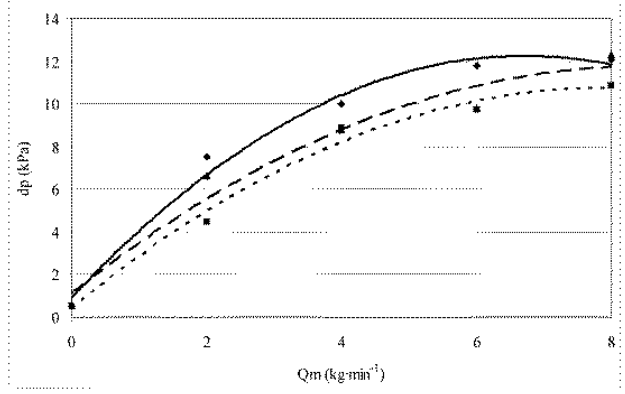

C)

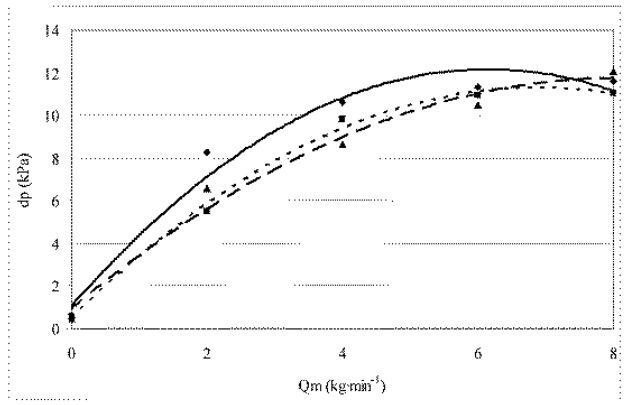

B)

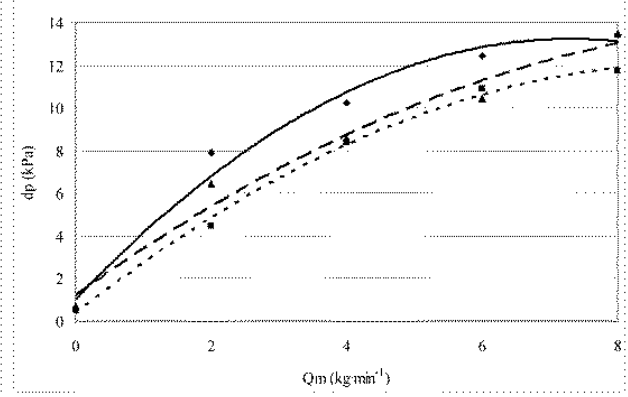

- $\mathrm{B}=\mathrm{MD} \triangle \mathrm{MK}$

Symbols

$\mathrm{B}$ - bioniiker cluster

MD - cluster with vented teat gums

MK- cluster with air supply to a claw

Figure 5. Impact of mass intensity of liquid flow Qm on underpressure fluctuations in the $d p$ cycle in the investigated variants of clusters for penetration of a teat $P e=62 \mathrm{~mm}$ at the systemic underpressure: $A-46 \mathrm{kPa}, B-48 \mathrm{kPa}, \mathrm{C}-50 \mathrm{kPa}$

\section{Conclusion}

1. Results of a multi-factor analysis of variance indicate a significant (at the level $\alpha=0.01$ ) impact on the selected parameters of milking pss, dpsr and dp of the manner of air supply to a cluster (variant of a cluster), teat penetration, mass intensity of milk replacing liquid flow and the set working vacuum. Impact of the last factor proved to be significant for the dp parameter.

2. Application of vented triangle liners in a cluster resulted in a considerable reduction of average vacuum of suction pss in comparison to the remaining two clusters with different manners of air supply.

3. From among three variants of clusters used for the research, from which every has a different manner of air supply to a milking installation, the lowest vacuum fluctuations in dp cycle is generated by a cluster with vented liners with a triangle cross-section of tubes, by $5-10 \%$ higher by a cluster with air supply to a claw and with non-vented triangle liners and the highest by a cluster with a single air supply to the connection pipe of a liner - biomilker. 
4. The use of vented liners as the system of air supply to a cluster, which operates the most favourably under the conditions of mechanical milking, requires further research mainly on the impact of big amounts of air supply on the quality of obtained milk.

\section{References}

Harms, J. (2009). Automatisches Melken - Stand der Technik und Entwicklungstendenzen. ARTSchriftenreihe, 9, 105-113.

Hofelmayer, T., Meier, T. (1979). So arbeitet der Bio-Milker. Milchpraxis, 17, 64-65.

Kerkhof, J.A. (1972). Drop of vacuum in milk lines. Research Report 2, Inst. of Agricultural Engineering and Rationalization, Wageningen.

Kupczyk, A. (1999). Doskonalenie warunków doju mechanicznego ze szczególnym uwzględnieniem podciśnienia w aparacie udojowym. Inżynieria Rolnicza, 3(9), 114.

Lipiński, M., Czarnociński, F. (1995). Analiza zmian podciśnienia zachodzących w aparacie udojowym Harmony. Roczniki AR Poznań, Rolnictwo, 46, 45-51.

Luberański, A., Pruski, K., Wiercioch, M. (2013). Metoda komputerowego wspomagania obliczeń ciśnieniowych parametrów mechanicznego doju i nacisków masujących strzyk. Agricultural Engineering, 3(146), 235-242.

Nodegren, S.A. (1980). Cyclic vacuum fluctuations in milking machines. Dissertation. Hohenheim.

Rasmussen, M.D., Madsen, N.P. (2000). Effects of milkline vacuum, pulsator airline vacuum, and cluster weight on milk yield, teat condition, and udder health. Journal of Dairy Science, 83 , 77-84.

Rasmussen, M.D., Wiking, L., Bjerring, M., Larsen, H.C. (2006). Influence of air intake on the concentration of free fatty acids and vacuum fluctuations during automatic milking. Journal of Dairy Science, 89, 4596-4605.

Rossing, W. (1970). Air consumption of milking machine installations and the required capacity of the vacuum pump. Inst. of Agricultural Engineering and Rationalization, Wageningen. Research Report 4.

Szlachta, J., Wiercioch, M. (1984). Analiza zmian podciśnienia i parametrów doju w komorach kubka udojowego z periodycznym doprowadzeniem powietrza. Roczniki Naukowe Zootechniki, Monografie i Rozprawy, 22, 325-335.

Szlachta, J. (1986). Studia nad wybranymi elementami budowy i użytkowania aparatu udojowego Zeszyty Naukowe AR Wrocław, Rozprawy, 58, ISSN 0209-1321.

Szlachta, J., Wiercioch, M. (1988). Wpływ dojarek na jakość doju. IBMER Warszawa, OORiDR SITR Wrocław.

Wiercioch, M. (1994). Przepływy w kubku udojowym dojarki mechanicznej. Zeszyty Naukowe AR we Wrocławiu, Rozprawy, 260, ISSN 0867-1427.

Wiercioch, M., Luberański, A., Krzyś, A., Skalska, D. (2013). Analiza i modelowanie wahań podciśnienia w aparacie udojowym w relacji zmian pojemności komory mlecznej kolektora. Agricultural Engineering, 4(147), T.1, 383-392.

Vetter, A., van Dorland, H.A., Youssef, M., Bruckmaier, R.M. (2014). Effects of a latency period between pre-stimulation and teat cup attachment and periodic vacuum reduction on milking characteristics and teat condition in dairy cows. Journal of Dairy Research, 81, 107-112.

ISO - 5707:(1983). Milking machine installations. Construction and performance.

ISO - 5707:(2007). Milking machine installations. Construction and performance.

ISO - 6690:(2007). Milking machine installations - Mechanical tests.

www.1 Obtained from: http://www.milkrite.com/US/Products/impulse air.htm.

www.2 Obtained from: http://www.apagro.pl/HeroGraf/do_pobrania/top_agrar1.jpg.

www.3 Obtained from: http://www.apagro.pl/HeroGraf/do_pobrania/top_agrar2.jpg. 
Impact of the system...

\section{WPLYW SYSTEMU DOPRAWADZANIA POWIETRZA DO JEDNOSTKI UDOJOWEJ NA WYBRANE PARAMETRY PRACY APARATU UDOJOWEGO}

Streszczenie. Doprowadzanie powietrza do instalacji aparatu udojowego, które ułatwia odpływ mleka do rurociągu mlecznego oraz poprawia stabilizację podciśnienia i ogranicza jego wahania, realizowane jest najczęściej w sposób ciągły przez dopływ niewielkiej ilości powietrza do komory mlecznej kolektora względnie w sposób periodyczny do króćca mlecznego gumy strzykowej. Na rynku urządzeń udojowych pojawiło się nowe rozwiązanie w postaci gum strzykowych wentylowanych - impulseair $^{\circledR}$, w których dopływ powietrza następuje w sposób ciągły przez kalibrowaną dyszę w główce gumy strzykowej. Celem pracy była analiza i ocena wybranych parametrów doju wyznaczonych $\mathrm{w}$ aparacie udojowym z kolektorem o stałej pojemności komory mlecznej $\left(250 \mathrm{~cm}^{3}\right)$ z wentylowanymi gumami strzykowymi na tle innych rozwiązań stosowanych do doprowadzania powietrza w aparatach udojowych. Pomiary przeprowadzono $\mathrm{w}$ warunkach laboratoryjnych przy doju przemiennym do rurociągu mlecznego górnego, przy zmiennych masowych natężeniach przepływu cieczy (w zakresie 0-8 $\left.\mathrm{kg} \cdot \mathrm{min}^{-1}\right)$ dla trzech wartości podciśnień systemowych $(46,48$ i $50 \mathrm{kPa})$ oraz przy pięciu penetracjach sztucznych strzyków. Wykazano, stosując analizę statystyczną, istotny wpływ sposobu doprowadzania powietrza do aparatu udojowego oraz pozostałych zmiennych niezależnych doświadczenia na wybrane parametry doju. Stwierdzono, że aparat udojowy z gumami strzykowymi wentylowanymi, choć najbardziej obniża średnie podciśnienie ssania pss to jednocześnie najlepiej ogranicza wahania podciśnienia w cyklu dp.

Słowa kluczowe: dój maszynowy, aparat udojowy, gumy wentylowane, parametry doju 